實驗結果 次表及第 4 圖の結果を得た。

燒成
配合
SK15度

本實驗の結果に依れば水硬率及珪酸率又は是等と鐵率とを一定し單に $\mathrm{Cr}_{2} \mathrm{O}_{3}$ を添加せる場合に 於ても明か に强度が增加する。佾石灰石と大峠白土とのセメントは白色セメントであつて，之に $\mathrm{Cr}_{2} \mathrm{O}_{3}$ を添加したセメ ントは群明な綠色セメントである。

\title{
6 要旨
}

水硬率 2.05 2.14 のポルトランドセメントに於て $\mathrm{CaO}$ 及 $\mathrm{SiO}_{2}$ の含有率を一定し, $\mathrm{Cr}_{2} \mathrm{O}_{3}$ を以て $\mathrm{Al}_{2} \mathrm{O}_{3}$, $\mathrm{Fe}_{2} \mathrm{O}_{3}$ の一部分を置換したもの 14 種, 水硬率 2.30 のポルトランドセメントに於て水硬率及 $\mathrm{CaO}$ の含有 率を一定し $\mathrm{Cr}_{2} \mathrm{O}_{3}$ を以て $\mathrm{SiO}_{2}, \mathrm{Al}_{2} \mathrm{O}_{3}$ 及 $\mathrm{Fe}_{2} \mathrm{O}_{3}$ の一部分を置換したもの 4 種並に石灰石及大峠白土を原料 之し水硬率 2.15 の白色ポルトランドセメントに於て水硬率, $\mathrm{CaO}$ 及 $\mathrm{Fe}_{2} \mathrm{O}_{3}$ の含有率を一定し $\mathrm{Cr}_{2} \mathrm{O}_{3}$ をと $\mathrm{SiO}_{2}$ 及 $\mathrm{Al}_{2} \mathrm{O}_{3}$ の一部分を置換したもの 2 種を試製して小型耐厚力を比較した。

何れの場合に於ても酸化クロムは明かに 1 28 日の普通硬化强度及 4 週聯結硬化强度を增進した。併し酸 化クロムの效果は他成分の比に依て幾分か變化するやうである。

終りに本研究は財團法人高松記念資金財團の援助に依つたものである。立に同財團に對して樑い感謝を捧げ る。(東京工業大學穑業學科) (昭和 9 年 7 月 20 日受理)

\section{セメント间轉弿のヒートバランスの吟味（第 2 報）}

\section{吉 井 豐 藤 丸}

(The Investigation of Heat Balances of Cement Rotary Kiln (part 2)

By Toyofujimaru Yoshii

\section{B. 濕式问轉䵟のヒートパランスの計算}

本計算は $2.85 \times 3.45 \times 60.9$ のウナックスキルン゙の順調なる場合につき試驗し計算したるものにして其時の原

* kiln は嚴格にいいばキル (kil) と發夏すべきであるがこっでは日本の慣習に從ひキルンとしておく。 
料化學成分, 使用石炭從つて其石炭灰分其他の計算の基準等は全然乾式の啺合と同一なり。唯原料に $34 \%$ の 水を含む爲に標當り燒成用炭は $51.2 \mathrm{~kg} / \mathrm{bbl}=0.3103 \mathrm{~kg} / \mathrm{kg} . \mathrm{cl}$. なること〉飛散ダストの分量及其成分從つて椗 當り所要原料は乾式の場合とは稍趣を異にして居る。これを表示すれば次の如し。

\begin{tabular}{|c|c|c|c|c|c|c|c|}
\hline 原料生物 & 原料燒成物 & & 炭灰分 & & ダスト & & クリンカー \\
\hline 1582.8 & 1028.8 & + & 27.9 & - & 56.7 & $=$ & $1000.0 \mathrm{~g}$ \\
\hline
\end{tabular}

Chemical compositions of flue dust (wet process)

$\begin{array}{lccl}\text { Ig. Loss } & 11.80 \% & \mathrm{SiO}_{2} & 17.29 \% \\ \mathrm{Al}_{2} \mathrm{O}_{3} & 5.59 & \mathrm{Fe}_{2} \mathrm{O}_{3} & 2.27 \\ \mathrm{CaO} & 53.10 & \mathrm{MgO} & 1.23 \\ \mathrm{SO}_{3} & 5.25 & \text { remainder (alkalies, etc.) } & 3.47 \\ \text { Total } & 100.00 & & \end{array}$

\section{1. クリンカー燒成及水分蒸發に要する熱}

上に示すが如く $1 \mathrm{~kg}$ のクリンカーを燒くに要する原料は $1.5828 \mathrm{~kg}$ にして之を更に粘土, 石灰石, 及鐵鑛 等の各原料成分に振分ける時は其內譯は次の如くになる。

Table. 8

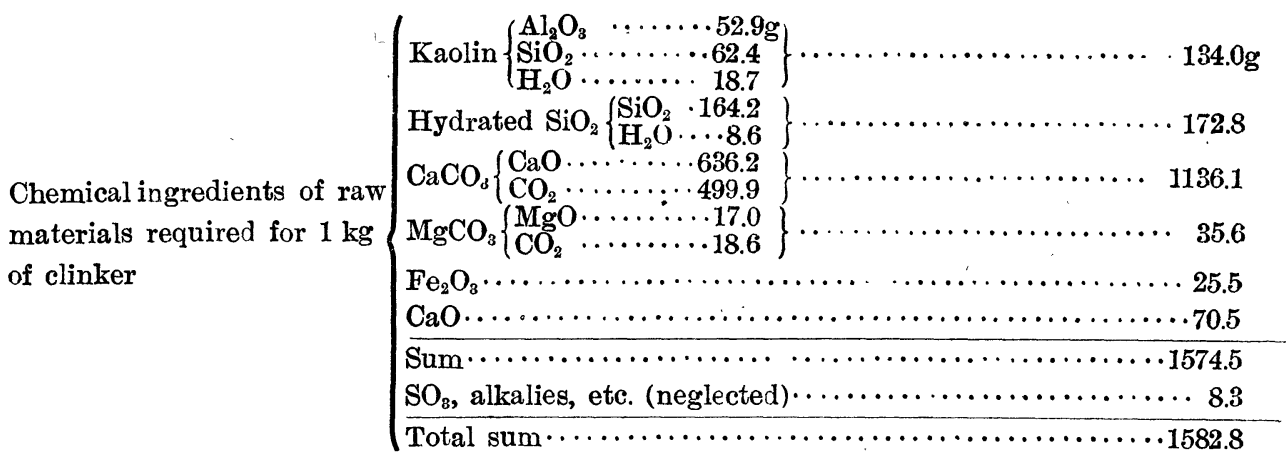

a. $\mathrm{CaCO}_{3}$ の加熱及分解に要する熱

乾式の場合と同樣の計算を行へば下の如し。 $15^{\circ}$ から $800^{\circ} \mathrm{C}$ 迄加熱するに要する熱 分解用熱 $\left(800^{\circ} \mathrm{C}\right)$

\begin{tabular}{|c|c|}
\hline \multirow{2}{*}{\multicolumn{2}{|c|}{$1.1361 \times(800-15) \times\left({ }^{(\mathrm{O})}\right) \times 0.267=238.1$}} \\
\hline & \\
\hline 合 & 668 \\
\hline
\end{tabular}

b. $\mathrm{MgCO}_{3}$ の加熱及分解に要する熱 $15^{\circ}$ から $650^{\circ} \mathrm{C}$ 汽加熱するに要する熱 分解用熱 $\left(@ 650^{\circ} \mathrm{C}\right)$

\begin{tabular}{|c|c|}
\hline \multirow{2}{*}{\multicolumn{2}{|c|}{ 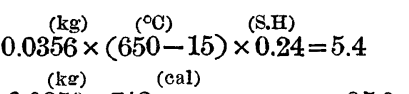 }} \\
\hline & \\
\hline 合 & 30 . \\
\hline
\end{tabular}

c. 遊離の $\mathrm{CaO}$ を加熱するに要する熱 $15^{\circ}$ から $800^{\circ} \mathrm{C}$ 汽加熱するに要する熱 $0.0705 \times(800-15) \times 0.219=11.7 \mathrm{cal}$.

d. $\mathrm{Fe}_{2} \mathrm{O}_{3}$ を加熱するに要する熱 $15^{\circ}$ から $800^{\circ} \mathrm{C}$ 迄の加蓺用熱 $0.0255 \times 0.2988 \times(8000-15)=6.0 \mathrm{cal}$. 
e. 苏オリンの加熱及分解に要する熱

$15^{\circ}$ 加穴 $800^{\circ} \mathrm{C}$ 迄の加熱及分解用熱

$0.134 \times 352=47.2 \mathrm{cal}$

f. 含水珪酸の加熱及分解

$15^{\circ}$ 力ら $800^{\circ} \mathrm{C}$ 迄の加熱及分解用熱

$0.1728 \times 244.4=42.2 \mathrm{cal}$

g. クリンカーを $800^{\circ} \rightarrow 1450^{\circ} \mathrm{C}$ に熱するに要する熱

$$
\left.\stackrel{(\mathrm{kg})}{1} \times(1 \stackrel{(}{\circ} \mathrm{C})^{4} \mathrm{0}-800\right) \times \stackrel{(\mathrm{S} . \mathrm{H})}{0.290}=188.5 \mathrm{cal} / \mathrm{kg} . \mathrm{cl}
$$

h. クリンカーの發熱反應

Nacken 氏に從ひ其發熱量を $100.0 \mathrm{cal} / \mathrm{kg} . \mathrm{cl}^{\prime}$ とす。

i. クリンカーが鸴內で冷めて四收される㷫

$1450^{\circ} \mathrm{C}$ のクリンカーが $1200^{\circ} \mathrm{C}$ (筭出口に於ける溫度) 迄冷却され其失ら爇は路熱空氣として再国收される。 $\mathrm{Q}_{1450 \sim 1200^{\circ} \mathrm{C}}=\stackrel{(\mathrm{cal})}{372.9-292.0=80.9 \mathrm{cal} / \mathrm{kg}^{(\prime \prime} \mathrm{cl}^{\prime}}$

j. 原料の分解によつて生ずる瓦斯のもつ熱

$\mathrm{CaCO}_{3}$ 中の $\mathrm{CO}_{2}$ のむつ熱 $(0.4999-0.0084) \times(800-15) \times 0.253=97.6 \mathrm{cal}$.

$\mathrm{MgCO}_{3}$ " $\mathrm{CO}_{2}$ " $0.0186(650-15) \times 0.246=2.9$ "

カオリン中の水分より來る熱 $0.0187 \times(800-15) \times 0.484=7.1$ ”

含水珪酸 ”

0.0086

$\frac{\times(400-15) \times 0.470=1.6 \mathrm{\prime \prime}}{\text { 合 } \quad \text { 話 } \quad=109.2 \mathrm{ca}^{1} / \mathrm{kg} . \mathrm{cl}^{\prime}}$

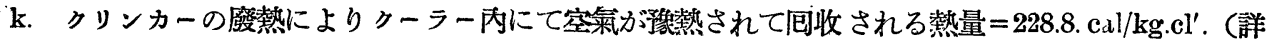
細後出)

故にクリンカー $1 \mathrm{~kg}$. をやくに要する正味所要熱量 $\left(\mathrm{Qcl} \mathrm{l}^{\prime}\right)$ は

$$
\begin{aligned}
\mathrm{Qcl}^{\prime} & =\frac{\mathrm{a}+\mathrm{b}+\mathrm{c}+\mathrm{d}+\mathrm{e}+\mathrm{f}}{1028.8\left(=\text { 原料燒成物重量 } \mathrm{kg} / \mathrm{kg} . \mathrm{cl}^{\prime}\right.}+\mathrm{g}-(\mathrm{h}+\mathrm{i}+\mathrm{j}+\mathrm{k}) \\
& =784.1+188.5-(100.0+80.9+109.2+228.8)=453.7 \mathrm{cal} / \mathrm{kg} . \mathrm{cl}^{\prime} \text { なり。 }
\end{aligned}
$$

1. スラリー中の水分の蒸發用潜熱

スラリーは $34 \%$ の水分を含む故々の水量は次の如し。

$1.5828 \mathrm{~kg} \times 34 / 66=0.8154 \mathrm{~kg} / \mathrm{kg} . \mathrm{cl}^{\prime}$

スラリー中の水分が $15 \bullet \rightarrow 100^{\circ} \mathrm{C}$ に熱せられるに要する熱 $0.8154 \times(100-15) \times 1.0044=69.6 \mathrm{cal}$.

同蒸發用潜熱 $\ldots \ldots \ldots \ldots \ldots \ldots \ldots \ldots \ldots \ldots \ldots . . .6154 \times 539.9$

$100^{\circ} \mathrm{C}$ のスチームを $15^{\circ} \mathrm{C}$ のスチーム

・に冷却した場合に論理上吐出守熱量 $\}$

$\begin{array}{cl}\cdots 0.8154 \times 539.9 & =440.2 \prime \prime \\ \text { 合 } \quad \text { 計 } & =509.8 \prime \prime\end{array}$

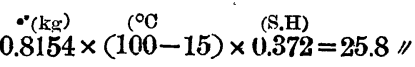

差引 $\left(15^{\circ} \mathrm{C}\right.$ ঐ水を $15^{\circ} \mathrm{C}$ のスチームにするに要する熱) $\quad=484.0 \mathrm{cal} / \mathrm{kg} . \mathrm{cl}^{\prime}$.

\section{2. クリンカーの\&つ糜熱}

クリンカーがクーラーから出る溫度は本均 $180^{\circ} \mathrm{C}$ なる故其中に含まるる熱量は $Q_{180^{\circ}-15^{\circ}}=32.7 \mathrm{cal} / \mathrm{kg} . \mathrm{cl}^{\prime}$ な り。

\section{3. クーラーのセルから逃げる熱及潗熱空氣による回收熱}

輻射によるもの $=12.9 \mathrm{cal}$. 


$\begin{array}{ll}\text { 對流によるもの } & =14.9 \mathrm{Ca} . \\ \text { 合 計 } & =27.8 \mathrm{cal} / \mathrm{kg} . \mathrm{cl}^{\prime}\end{array}$

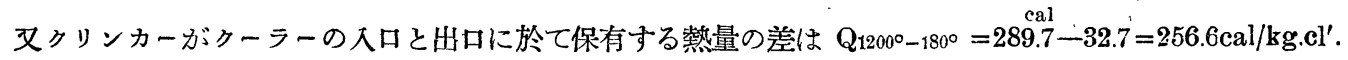
にしてこれより上の輻射及對流による熱損を差引きたる $256.6-27.8=228.8 \mathrm{cal} / \mathrm{kg} . \mathrm{cl} \mathrm{I}^{\prime}$.が㐨熱空氣として回收さ るっことななる。

\section{4 弿のセルから失はる 熱量}

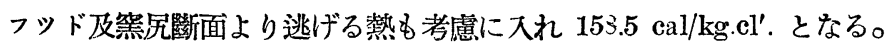

\section{5. 器に供給される空氣のもつ熱}

石炭の燃燒に要する空氣 $=7.7457 \times 0.3103=2.4012 \mathrm{~m}^{3}$

\begin{tabular}{ll} 
過剩空氣 $\left(1.8 \% \mathrm{O}_{2}\right.$ 談當 $)=$ & $=0.3576 "$ \\
\hline 空氣總量 & $=2.7588 ”$
\end{tabular}

$27588 \times 0.312 \times\left(20^{(\mathrm{H} 3)} \times 15\right)=4.3 \mathrm{cal} / \mathrm{kg} \cdot \mathrm{cl}^{\prime}$.

\section{6. 蟯成用岸の溫度より來る熱}

$0.3103 \times 0.25 \times\left(67^{(\mathrm{kg})} \stackrel{(\mathrm{S} . \mathrm{H})}{-15}\right)=4.0 \mathrm{cal} / \mathrm{kg} \cdot \mathrm{cl}^{\prime}$.

\section{7. 黑ススラリーの盢度より來る熱}

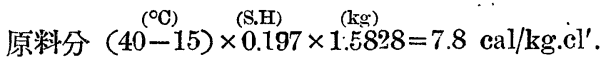

水 分 $(40-15) \times 0.9981 \times 0.8154=20.3 ”$
合 計 $28.1 ”$

\section{8. ダストによりて失はる】熱}

飛散ダストの溫度による蓺損(詳細後出) $\quad 0.0713 \times 0.28 \times\left(727.8^{(\mathrm{kg})} \mathrm{C}-15\right)=14.3 \mathrm{cal} / \mathrm{kg} \cdot \mathrm{cl} \cdot \mathrm{cl}$.

同 化學的潜熱 $0.071^{(\prime)} \times 784.1 \times\left(1-\frac{12.93 \%}{34.66 \%}\right)=35.1 "$

合 計 $=49.4$ "

\section{9. 廢ガスのもつ熱}

a. 石灰石から來るガス

$$
\begin{aligned}
& \mathrm{CaCO}_{3} \text { 中の } \mathrm{CO}_{2}=0.4999 \mathrm{~kg} \\
& \mathrm{MgCO}_{3} ”=0.0186 " \\
& \text { ダス中に殘る }=-0.0084 ” \\
& \hline \text { 差 } \quad=0.5101 " \\
& \therefore \frac{0.510(\mathrm{~kg})}{1.9632(")}=0.2598 \mathrm{~m}^{3} / \mathrm{kg} \cdot \mathrm{Cl}^{\prime} .
\end{aligned}
$$

b. カオリン及含水珪酸からくる水分

$$
\begin{gathered}
0.0187+0.0086^{(\mathrm{kg})}=0.0273 \\
\therefore \frac{0.0273(\mathrm{~kg})}{0.8038(\prime \prime)}=0.0340 \mathrm{~m}^{3} / \mathrm{kg}^{\prime \prime} \mathrm{cl}^{\prime} .
\end{gathered}
$$

c. 石炭の燃燒によるガス

$$
8.0953 \times 0.3103=2.5120 \mathrm{~m}^{3} \mathrm{~kg} \cdot \mathrm{cl}^{\prime} .
$$


d. スラリー中の水分

$$
\begin{aligned}
& \frac{0.8154(\mathrm{~kg})}{0.8038(/ /)}=1.0144 \mathrm{~m}^{8} / \mathrm{kg} . \mathrm{cl} \\
& \text { 以上合計 }=3.8202 . \mathrm{m}^{8} / \mathrm{kg} . \mathrm{cl}^{\prime} .
\end{aligned}
$$

之に完全燃焅を期する䈔 $1.8 \%$ の酸素相當の過剩空氣を用ひたる故其廢瓦斯總量は次の如くになる。

$$
3.8202^{\mathrm{m} 3} \div\left(1-\frac{1.8 \times 4.76}{100}\right)=4.1783 \mathrm{~m}^{8} \mathrm{~kg} . \mathrm{cl}^{\prime} .
$$

Table. 9

Mean specific heats of gases at constant pressure $\left(0 \sim t^{\circ} \mathrm{C} / \mathrm{n}-\mathrm{m} 3\right)$

$\begin{array}{cccc}\text { Gases } & \mathrm{CO}_{2} \& \mathrm{SO}_{2} & \mathrm{H}_{2} \mathrm{O} & \mathrm{O}_{2}, \mathrm{~N}_{2}, \mathrm{CO}, \mathrm{H}_{2}, \text { \& air } \\ \text { heatrange } & & & \\ 15^{\circ} \sim 600^{\circ} \mathrm{C} & 0.479 & 0.383 & 0.324 \\ 15^{\circ} \sim 770^{\circ} & 0.489 & 0.385 & 0.326 \\ 15^{\circ} \sim 800^{\circ} & 0.499 & 0.389 & 0.328\end{array}$

Table. 10

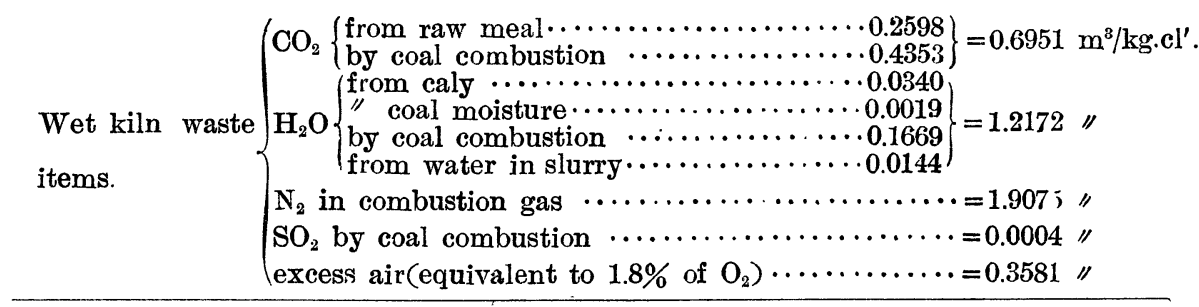

Total $\ldots \ldots \ldots \ldots \ldots \ldots \ldots \ldots \ldots \ldots \ldots \ldots \ldots+4.1783$ "

故に廢ガスのもつ熱量は上表を參照して第一報乾式の場合に於けるが如く詳佃なる計算を行へば次の如し。 (詳細後出)

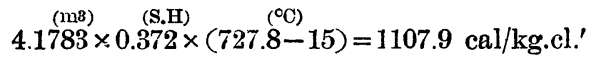

\section{0. ヒートパランスの總括}

以上を綜合して熱量の精算を行へば差引 $1122.2 \mathrm{cal}$ が廢ガス及其中に浮游するダストの保有すべき熱なり。 而して廢ガスとダストとは同溫度と見做しらべく今此溫度を $x^{\circ} \mathrm{C}$ とぜ第一報の式(1)により次の如く廢ガス 溫度を算出すること得。

$$
\begin{gathered}
4.1783 \times 0.372 \times(x-15)+1 \times \frac{7.13}{100} \times \frac{(\mathrm{S} . \mathrm{H})}{(\mathrm{kg})} \times 0.28 \times(x-15)=1122.2 \mathrm{cal} . \\
\therefore(x-15)=712.8^{\circ} \mathrm{C} \quad x=728^{\circ} 8 \mathrm{C}
\end{gathered}
$$

上の廢ガス溫度は濕式としては高すぎる故一見不審を抱かるつならんも此篣は乾式と同樣狳熱ボイラを附隨 しボイラーを生かす鴬故意に廢ガス溫度を高めたものである。

佾上のヒートバランスは此竿としても最も條件の良き場合に於けるものにして時には完全燃燒を期する篇に はこれ以上の過剩空氣を要することもあり，又時には石炭が不完全燃燒をなして甚しきは石炭のま入㖶道に飛

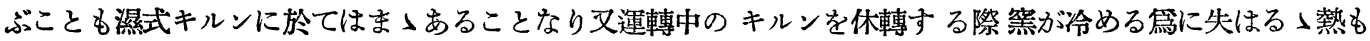
（追而發表の预定）亦等䦥に附すべからざるものにしてこれらを一切考慮に入れて長期にわたるヒートバラン をもとむる時は上のヒートバランスよりも惡くなり從而檴當り所要石炭量も多くなるを常とする。然れどもこ 
Fig.: 3

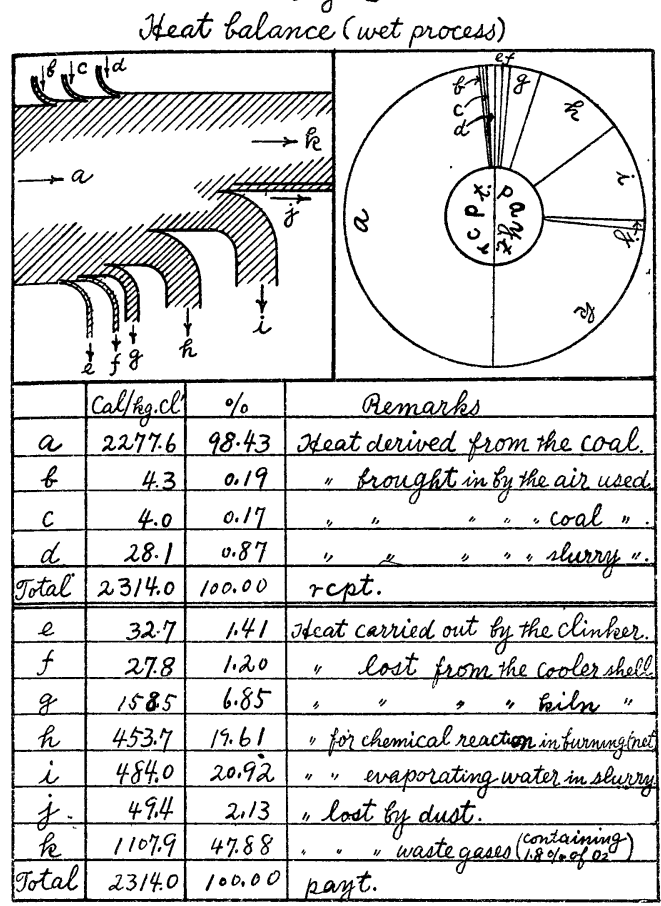

れは細心の注意と不斷の研究とによつて或程度汽哙 とめ得べきものである。

以上計算の結果より得をるヒートバランスを一括 表示すれば Fig. 3 の如くになる。

\section{II. 石宸の烧堯效率}

以上は廢ガス中に $1.8 \%$ の酸素を含む場合のヒ一 トバランスなり。然るに乾式の場合と同樣理想煂燒 の場合の計算を行へば次の如し。

a. 石炭が理想燃燒をなしたる場合

廢ガスの溫度を前同樣 $728.9^{\circ} \mathrm{C}$ とし理想燃燒をな したる䉆に前の場合よりも $x_{1}{ }^{\prime} \mathrm{kg} / \mathrm{kg} . c 1$. の石炭が節 約されたと假定す。然るときは干式の場合と同樣次 式を得べし。 $x_{1}=0.3103-$

$(0.3103 \times 7340)-1107.9+(0.376 \times 1.3082 \times 712.8)$ $7340-(8.0953 \times 0.376 \times 712.8)$

$=0.3103-0.2940=0.0163 \mathrm{~kg} / \mathrm{kg} \cdot \mathrm{cl}^{\prime}$.

依而理想燃墝の場合の石炭の燃燒效率を $100 \%$ と

せば $1.8 \%$ の過剩酸素該當の空氣を用ひて完全燃燒したる場合の燃燒效率 $E_{1}^{\prime}$ は次の如し。

$$
E_{1}^{\prime}=\frac{100 \times 0.2940}{0.3103}=94.75(\%)
$$

b. 石炭が不完全然焥をなし廢ガス中に $1.8 \%$ の 00 ガスを含む場合

次に比較の爲廢ガス中に $1.8 \%$ の CO ガスガ存在せる場合に付第一報乾式の場合の式(3)及(4)を適用して 計算すれば下の如し。

$$
\begin{aligned}
y^{\prime} & =\frac{1.8 \times[1.3082 \times 7340+8.0953 \times(1206.1-36.4)]}{1.00 \times 1.4027 \times[7340-8.0953 \times 0.374 \times(727.8-15)]-1.8 \times[(7340 \times 5.4283)-(8.0953 \times 309])]} \\
& =0.0490 \mathrm{~kg} / \mathrm{kg} . \mathrm{cl}^{\prime} .
\end{aligned}
$$

次に $x_{2}{ }^{\prime}=0.049 \times\left(\frac{100 \times 1.4027-1.8 \times 5.4283}{1.8 \times 8.0953}\right)-\frac{1.3082}{8.0953}=0.4388-0.1616=0.2772 \mathrm{~kg} / \mathrm{kg} . \mathrm{cl}^{\prime}$.

故に $\quad x_{2}{ }^{\prime}+y^{\prime}=0.2772+0.0490=0.3262 \mathrm{~kg} / \mathrm{kg} . \mathrm{cl}^{\prime}$. となる。

從つて理想燃燒に對するこの場合の燃燒效率 $\left(E_{2}^{\prime}\right)$ は次の如く低下す。

$$
E_{2}^{\prime}=\frac{100 \times 0.2940}{0.3262}=93.13(\%)
$$

\section{結豆}

以上乾濕兩樣の場合につきいづれも實測に基いて各ヒートバランスをもとめたり。兩者を比較する時は各々 の項に於て夫々差異があるこれもとより乾式と濕式との差によること勿論なれどもキルシの構浩に依存するこ と亦大なり。即乾式に於ける案のセルの熱損失が少くしてクーラーの熱損失の多き濕式に於て窐のセルの熱損 失が多くしてクーラーの熱損失の少きが如しこれは前者は普通のロータリーキルンに配するにドラムクーラー 


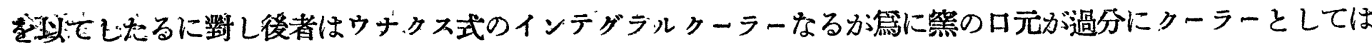
たらいて居るが爲である。

其他クリンカー燒成用の正味所要熱量の多寡はクーラーのタイプがことなる篇ホットエヤー利用率の多少に よるものなり。

從つて上記の結果を以て值に一概に乾濕兩樣のヒートバランスの本質的相違と見做すことは早計である。

著者はこっではヒートバランス計算の根本にふれて乾濕兩樣式を比較することは勿論なれども更に䈍のタイ

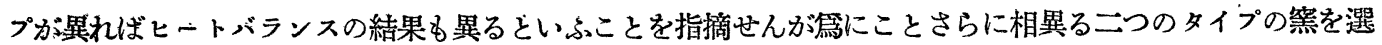
んだわけである。

故に若し乾濕兩樣式のみを比較せんと欲せば寧同一タイプの筧を用ひあらゆる條件を可及的同一にして比較 試驗すべきるのにして著者はこれを別の機會に讓りたいと思ふっ。

終に本研究にあたり直接或は間接に御楒篤なる御指導並に御援助を賜りたる恩師東京工業大學教授近藤淸治 博士，同木下正雄博士及秩父セメント株式會社常務取締役大友幸助氏に對し深厚なる謝意を表す。

\section{要 旨}

1. 從來のヒートバランスの大きな誤謬はキルン及クーラーのセルの輻射及對流熱損の測定及計算法の不備 に起因寸ること多し。

依而著者は自ら考案するところの『線膨脹法』によつて其輻射及對流熱損を精查して正しきヒートバラン スを作製せんとせり。

2. 從來のヒートバランスに於て閑却されたるダストによる熱損失がヒートバランスに重大なる役割を演ず ることを指摘す。

3. ヒートバランスの訫算法を明にして其實用化をはかり筧の各條件及著者が提晿する『燃燒效率』の向上を 企圖す。[完]

\section{參考交 嗝}

G. Martin, Chem. Eng. \& Thermodynamics applied to Cement rotary kiln. 1932.

H. Kühl \& Knothe. Chemie der hydraulischen Bindmittel. 1915.

Hans Bussmeyer. Wärmewirtschaft in der Zementindustrie. 1931.

燃料協會編 實用燃料便覽昭和七年 （昭和 9 年 8 月 18 日受理）

\section{本交第一報（第四百九十七號）正誤表}

\begin{tabular}{|c|c|c|c|}
\hline 頁 & 行 & 正 & 諤 \\
\hline 295 & 3 & Balance & Balances \\
\hline " & 20 & wet & wel \\
\hline " & 28 & Kühl & kühl \\
\hline " & " & Koch & koch \\
\hline " & 29 & Walter Knothe & walter Knothe \\
\hline " & 30 & chemie & Chemie \\
\hline " & 33 & Clinker の略 & Clinker, 略 \\
\hline 296 & 22 & 振分け & 擴げ \\
\hline " & 41 . & $15^{\circ} \rightarrow 800^{\circ} \mathrm{C}$ & $15^{\circ}-800^{\circ} \mathrm{C}$ \\
\hline
\end{tabular}




\begin{tabular}{|c|c|c|c|}
\hline 297 & 1 & $\mathrm{Q}_{300^{\circ} \mathrm{C}}=379.2 \mathrm{cal} / \mathrm{kg} \cdot \mathrm{CaCO}_{3}$ & $\mathrm{Q} 800^{\circ} \mathrm{C}=-379.2 \mathrm{cal}$. \\
\hline " & 7 & Meade & Meacle \\
\hline " & " & $712 \mathrm{cal} / \mathrm{kg} \cdot \mathrm{MgCgCO}_{3}$ & $712 \mathrm{cal} / \mathrm{kg}$ \\
\hline " & 23 及27 & $15^{\circ} \rightarrow 800^{\circ} \mathrm{C}$ & $800^{\circ} \mathrm{C}$ \\
\hline 297 & 29 & 0.1822 & 182.2 \\
\hline " & 24 & by A. S. Herschel & by. Q. A. S. Herschel. \\
\hline 298 & 6 & $100.0 \mathrm{cal} /{\mathrm{kg} . c l^{\prime}}^{\prime}$ & $100.0 \mathrm{cal} / \mathrm{kg} . \mathrm{C}$ \\
\hline " & 16 & 9.1 & 7.0 \\
\hline " & 27 & 0.009 & 0.091 \\
\hline " & 33 及 35 & Qcl. & $\mathbf{Q d}$ \\
\hline 299 & 13 & 供給される空氣 & 供給さる外氣 \\
\hline " & $\begin{array}{l}14 \\
\prime \prime\end{array}$ & $\begin{array}{l}0.312 \\
3.0 \mathrm{cal}\end{array}$ & $\begin{array}{l}0.241 \\
2.3 \mathrm{cal}\end{array}$ 原稿の諨記從而以下の本交計 \\
\hline " & 25 & 以下の熱 & 以下熱 \\
\hline 300 & 5 & カオリン & カホリン \\
\hline " & 27 & Gases per kg coal. & Gasses from coal $1 \mathrm{~kg}$ \\
\hline " & 28 & complete & complets \\
\hline " & 30 & $\mathrm{CO} \rightarrow 1752.4$ & 1752.4 \\
\hline 301 & Fig 1 の下及 29 & gases & 原稿訂正 \\
\hline " & 28 & gases per $n-m^{3}$ at const' press'. & gasses at const' press $1-\mathrm{nm}^{3}$. \\
\hline " & 35 & 廢ガス & 塺ガスト \\
\hline " & 36 & D.Sd. $\left(x-15^{\circ}\right)$ & D.Sd: $\left(x-15^{\circ}\right)$ \\
\hline 302 & 27 & $\left(\mathbf{Q}_{0}-x_{1} \mathbf{Q C}\right)$ & $\left(\mathrm{Q}_{0}-r_{1} \mathrm{H}\right)$ \\
\hline " & 30 & c & $\mathbf{C}$ \\
\hline " & 36 & $\left(15^{\circ} \mathrm{C}\right)$ & $\left({ }^{\circ} \mathbf{C}\right)$ \\
\hline 303 & 14.15 & 理想燃燒 & 完全燃燒 \\
\hline " & 30 & $\left(@ \mathbf{T} \sim \mathbf{t}^{\circ} \mathbf{C}\right)$ & $\left(@ \mathbf{T}-\mathbf{t}^{\circ} \mathbf{C}\right)$ \\
\hline 304 & 4 & 煩雜 & 繁雜 \\
\hline " & 8 & 論評 & 諭詳 \\
\hline " & 12 . & 證左 & 證查 \\
\hline
\end{tabular}

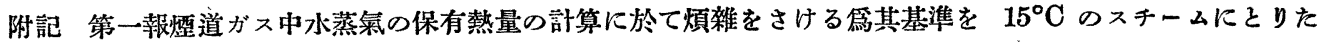
り。然るに嚴格にいいば第二報濕式の場合に於けるが如く $15^{\circ} \mathrm{C}$ の水に基準をとるべきるのにして後 者による時は計算上の煙道ガス溫度は前者によるよりも幾分低く出る。

\section{伯曹金子會䫒の御近情}

會頭には今春三月葉山別薡にて御大患に罹らせられ東京御本邸にて專ら御加盖中七月再 び葉山御別莊に赴かせられ御療美の處御經過盆々御良好にて昨今は御近傍御運動被遊るる 迄に被成候趣拜承誠に欣賀の至に不堪份新春々共に速かに御全快あらん事を新る次第であ ります斯に會頭閣下の御近情を會員に御知らせ致します。 